\title{
Profile of self-adjustment and level of academic stress during online learning in higher education
}

\author{
Husnul Azmiyyah* \\ PGRI Adi Buana University Surabaya \\ Gayungan, Surabaya, Jawa Timur, Indonesia \\ E-mail: husnulazmiyyah269@gmail.com \\ Ayong Lianawati \\ PGRI Adi Buana University Surabaya \\ Gayungan, Surabaya, Jawa Timur, Indonesia \\ E-mail: ayong@unipasby.ac.id
}

Received: July 22, 2021; Revised: August 06, 2021; Accepted: August 20, 2021

\begin{abstract}
This study aims at determining the profile of self-adjustment and academic stress levels during the online learning period of students at Faculty of Engineering PGRI Adi Buana University, Surabaya. The method used was survey quantitative research. The sampling technique used was a saturated sample for a more accurate representation. There were 200 students of total from department of industry, electrical, environment, urban planning, fashion, make-up, and gastronomy. The data collection techniques used were two questionnaires, namely selfadjustment and academic stress which were collected through online application. The data analysis technique used in this research was descriptive statistics. The results show that the selfadjustment of engineering faculty students was in the poor and high category. The adjustment aspect in the low category was found in the aspect of expressing feelings for $62 \%$, while the academic stress in the high category was found in the aspect of change for $78 \%$. It can be concluded that most of research participants during the online learning were still in a stable condition. However, there were several percentages of aspects that were less than perfect in the process of either self-adjustment or the level of academic stress.
\end{abstract}

Keywords: self-adjustment, academic stress, online learning, higher education

This is an open-access article under the CC-BY-SA license.

\section{Introduction}

The establishment of the rules for online learning through the letter of the Minister of Education and Culture of the Republic of Indonesia Number 4 of 2020 which instructs the process learning and teaching in the emergency period of the spread of Covid-19 that all learning activities are done at home. Educational institutions level from Playgroup to University levels are temporarily closed. Learning activities are carried out remotely. The changes in policy during this pandemic have an impact on the education sector, especially for higher education. The way of lectures that can be used as a solution during this pandemic is online learning (remote teaching). Online learning is a learning method with the help of an internet network to bring up various types of learning interactions based on accessibility, flexibility and connectivity (Moore et al., 2011). 
Online learning performed during this pandemic has created many perceptions for each individual, some may have a good perception because it will be something interesting and different. With a relaxed home situation, learning will be flexible and can also be balanced with other activities. However, there are also those who have the opposite perception. This circumstance is in line with what was found by Chita et all (Chita et al., 2020) in their research. The students are required to adapt quickly in the conditions and learning situations at home during the online learning period, and respond to instructions quickly and complete assignments on time.

The changes of the conditions that occur require a big effort for college students in the process of self-adjustment to start new habits towards learning changes. As stated by Handayani \& Yuca, (2018) explaining that the process of interaction and self-adjustment often cause feeling unprepared for college students in facing the current environment. It is in line with research findings (Haber \& Runyon, 1984) which say that good self-adjustment is seen on individuals who have an objective perception of reality to have the ability to adapt with pressure or stress, and are able to express emotions well. Based on this explanation, self-adjustment is one of the important components for the emerge of individual mental health. Individuals who have a healthy mentality can maximize their abilities in facing challenges, because an individual's personality is one of the factors that influence self-adjustment. Besides personality factors, there are several other factors that affect self-adjustment, such as social support and changes in new habit (Ward et al., 2001).

The change of a new life pattern causes individuals to be in a new environment so that the process of adjustment will become more difficult. This is because the stimulus received is basically different from one to another environment. The change of a new life pattern in this study indicates a new learning process. Students who are able to adapt with the changes in new learning patterns certainly face several problems during online learning. Research conducted by Rosali (Rosali, 2020) explains the problems of the students often complain are the availability of internet quota, unstable network connection, and supporting device (smartphones and laptops). In addition, the existence of various academic demands such as tasks that must be completed quickly, it triggers the occurrence of academic stress in college students (Livana et al., 2020).

Academic stress is a condition experienced by individuals when there are too many pressures and demands also there are some worries with exams and college assignments so that they cannot manage academic assignments properly due to a busy schedule (Dixit, 2019; Nurmalasari, et al., 2016). It is in line with the study conducted by Sandra (2015) which stated that academic stress is a stress which often appears because of the pressure to show an achievement and excellence in conditions where the academic competition increase. Therefore, they are burdened with all of the pressure and demandsThe pressures and demands that occur in current conditions force extremely and suddenly changes in conventional learning patterns to become an online learning without any preparation, which also affects the learning and teaching process. This learning process is not only performed in certain courses, but almost all courses are taught online.

Several previous studies related to online learning during the pandemic have been conducted, both to reveal the positive and negative aspects of online learning. One of study conducted is "Systematic review of the impact of online learning during the pandemic of covid19 towards Indonesian students"(Argaheni, 2020).

It was found that online learning caused several impacts to students, such as confusion and stress, less creative and less productive, being passive, an information accumulation or student concepts that were less useful and also the increasing of literacy skills. It should be underlined that this research extracted from several studies on the impact of online learning, but the systematic review was done on courses with theoretical bases that can still be accessed online. Whereas, there was a little research related to online learning on practical courses that should perform practical activities either in the laboratory or in workshops dealing with heavy equipment such as machinery, electronics and equipment that can only be taught by practice on it. 
During this pandemic, online learning is not only conducted by certain departments or study programs, but all majors or study programs are required to use online learning. Through interviews conducted by researchers for several students of the Faculty of Engineering, Universitas PGRI Adi Buana Surabaya batch 2019, some of them were confused about how to adapt and adjust to this online learning process, because they are used to do lectures and practice on campus together with other students. In addition, they complained about several academic problems such as assignments, ineffective learning processes and confusion in doing practical activities at home independently, and the satisfaction of material comprehension explained. The capability of lecturers here plays an important role, because even though they can provide good simulations through online learning, it does not fully solve the limitations in understanding the material compared to hands-on practice.

Based on the previous background, the researcher was interested in conducting a survey related to self-adjustment and academic stress level of engineering faculty students in Universitas PGRI Adi Buana Surabaya 2019 cohort. The results of this research will make the educators can give good feedback and pay more attention to mental health during the online learning, particularly for engineering faculty students who are also required to deepend hard skill and focus on work proficiency in accordance with the development of applied science and technology and the demands of employment needs.

\section{Method}

This study used a quantitative approach by survey research. Survey is one of quantitative methods which used to help doing an observation toward a social phenomenon in collecting the data which will be used to explain certain population which too large to be directly observed either to measure the behavior or the orientation of the certain group (Morrisan, 2018). This study used descriptive survey which strived to reveal the recent situation related to the selfadjustment profile and the level of the academic stress toward students of the Faculty of Engineering at PGRI Adi Buana University, Surabaya. The design used in this research was Descriptive Survey Design (Sugiyono, 2018).

The number of samples used in this study was the entire population. To meet the assumptions and objectives of the study, it was suitable for the researcher to use a saturated sample for a more accurate representation. Saturated sampling is a sampling technique when all members of the population are used as the samples. Respondents in the study were 200 students of the 2019 batch from the Faculty of Engineering, Universitas PGRI Adi Buana Surabaya, which covered seven engineering study programs, such as Industry, Electrical, Urban and Regional Planning, Environment, Culinary art, make-up and fashion. The data collection technique used an online questionnaire collected through google form.

Self-adjustment in this study was measured using a self-adjustment scale that was adapted and arranged based on the aspects of adjustment (Haber \& Runyon, 1984). Self-adjustment covers perception, stress management, self-concept, expression of feelings, and interpersonal relationships. Academic stress was measured using the Student Life Stress Inventory scale by (Gadzella et al., 2012) consisting of academic stressors such as frustrations, conflicts, pressures, changes, self-imposed, and also reactions to stressors namely Physiological, Emotional and Behavioral. The two scales were arranged and developed based on the research needs.

The data in this study were analyzed using descriptive statistics which the role is to ease the interpretation of data analysis systematically, factual and accurate manner and also to try to describe the phenomenon in detail in providing a description of the respondent's data profile. The data were analyzed based on the analysis of percentages and categories which are divided into a range of categories such as high, medium, and low based on the equation obtained from (Azwar, 2019) using SPSS program. 


\section{Findings and Discussion}

The results of the study are presented in the form of descriptive analysis using the SPSS 20.0 program. This survey was conducted as many as 200 engineering faculty students consisting of 7 study programs for the 2019 batch who are currently in the online learning period which are presented in the following data.

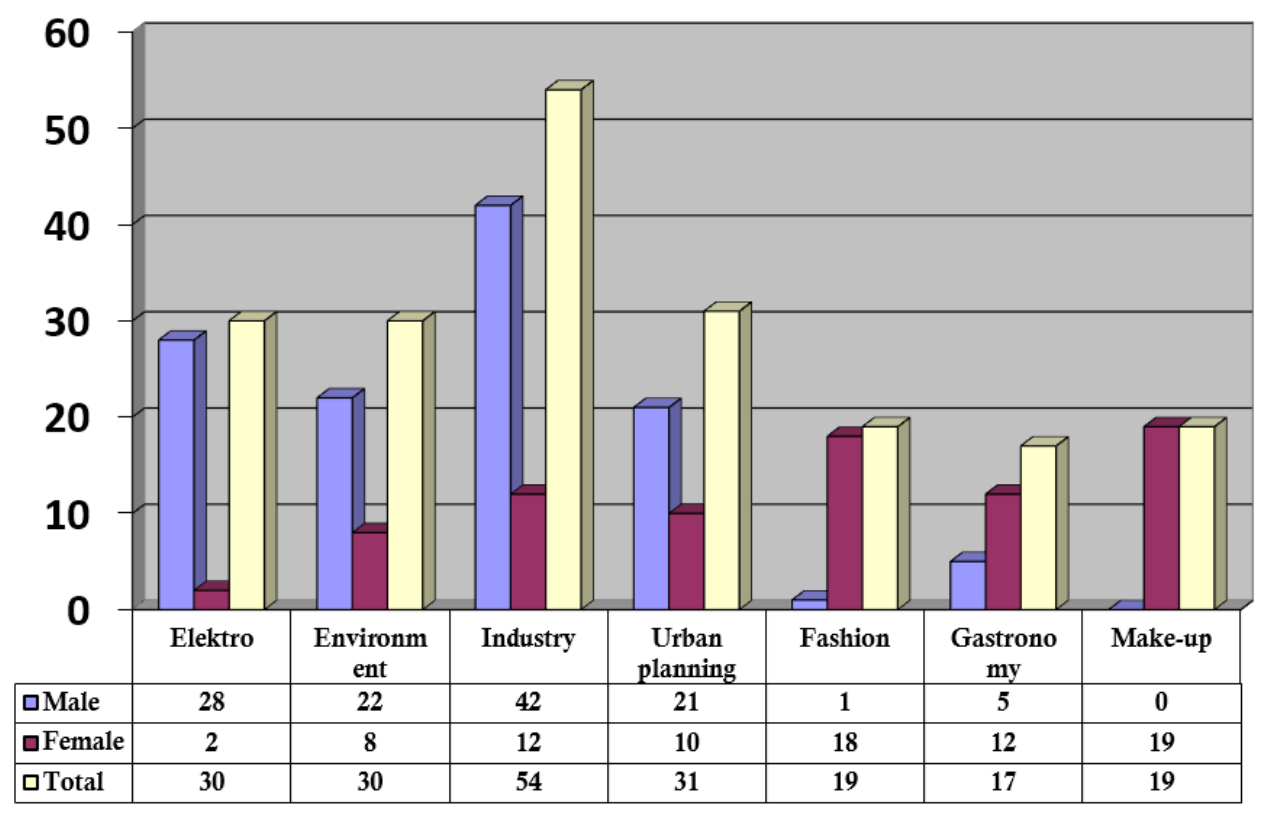

Figure 1. The Chart of the Respondent based on the study program

Descriptive statistical analysis is intended to obtain a profile picture of self-adjustment and levels of academic stress during the online learning period of the engineering faculty students of Universitas PGRI Adi Buana Surabaya. The following table will present the form of a frequency distribution classified into 3 categorizations, the category of self-adjustment are good, pretty good, and poor, and the category of academic stress are high, medium, and low with the following results.

\section{The Analysis of Self-adjustment during Online Learning period}

Table 1 The Frequency and Percentage of Self-adjustment during Online Learning Period

\begin{tabular}{cccc}
\hline Category & Interval & Frequency & Percentage \\
\hline Good & $19.6 \leq \mathrm{x}$ & 35 & $17.5 \%$ \\
Pretty good & $15 \leq \mathrm{x}<20$ & 133 & $66.5 \%$ \\
Poor & $x<15$ & 32 & $16.5 \%$ \\
Total & & 200 & $100 \%$ \\
\hline
\end{tabular}

The table 1. shows that the self-adjustment of engineering faculty students is in the poor category, such as 32 students with a percentage of $16.5 \%$. The result was based on several aspects that gave a poor self-adjustment impact on engineering faculty students .There are five aspects of self-adjustment developed in this study such as perception, stress management, positive selfimage, expression of feelings, and interpersonal relationships, and it is shown in the following chart. 


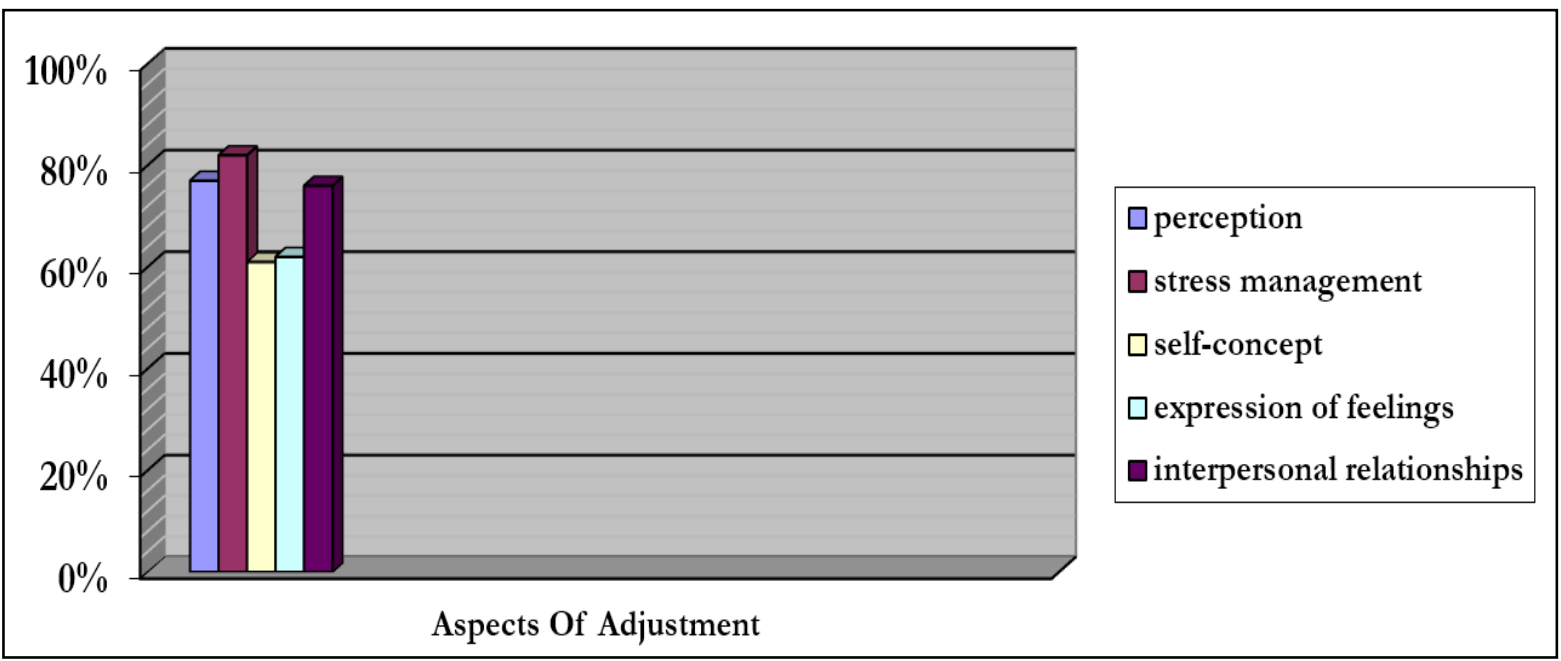

Figure 2. The Percentage of Self-adjustment Aspect

Based on the percentage of each aspect, the aspect of positive self-image (61\%) was the aspect with the lowest percentage. The aspect of expressing feelings $(62 \%)$ became the second lowest aspect experienced by engineering students in UNIPA Surabaya in the process of selfadjustment during the online learning. The aspect of positive self-image also affected the effectiveness of self-adjustment experienced by the individuals. This is in line with Safareka Yuliani (2017)'s statement that there is a significant relationship of self-image with the adjustment process. The higher the self-image possessed by the individual, the better the self-adjustment process. The ability in expressing feelings is needed in the adjustment process. If it is not performed properly, it can lead to imperfect self-adjustment processes. It is in line with the results of research (Nadlyfah \& Kustanti, 2018) that the higher the individual's self-disclosure, the better the self-adjustment process performed by individuals, it was also said that self-disclosure makes an effective contribution in influencing the self-adjustment process.

The Analysis of Academic Stress during the Online Learning Period be shown on table 2.

Table 2. Intensity of Academic Stress during Online Learning Period

\begin{tabular}{cccc}
\hline Category & Interval & Frequency & Percentage \\
\hline High & $22 \leq x$ & 36 & $18 \%$ \\
Medium & $12 \leq x<22$ & 133 & $66.5 \%$ \\
Low & $x<12$ & 31 & $15.5 \%$ \\
Total & & 200 & $100 \%$ \\
\hline
\end{tabular}

Based on the table above, it is known that academic stress on engineering students of UNIPA Surabaya at the high stress level of 36 students with a percentage of $18 \%$. The high category is dominated by female students. In fact, the academic stress developed in this study has 2 parts which are academic stressors and reactions towards stressors which include eight aspects such as frustration, conflict between two options, pressure, changes, self-imposed, physical reactions, emotional reactions, and behavioral reactions presented in the following graph. 


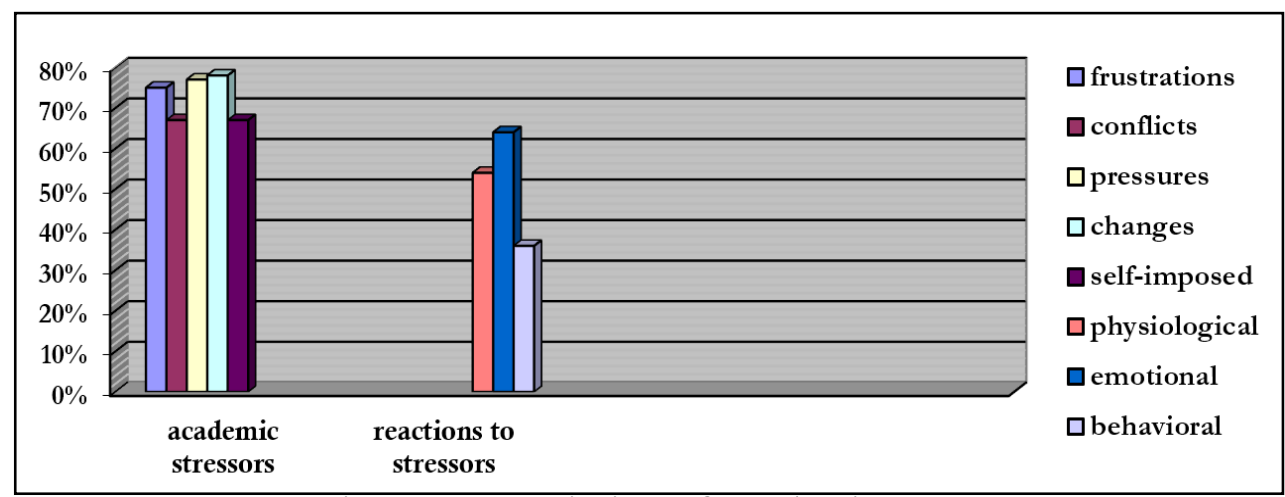

Figure 3. Description of Academic Stress Aspect

Based on the percentage per aspect, the aspect of change (78\%) was the aspect that is mostly felt by students, and the aspect of pressure $(77 \%)$ which was the change of the learning patterns causes a feeling of discomfort for engineering faculty students, and also the pressure in the online learning process that causes students feel uncomfortable such as a task weight, and inadequate facilities caused problems in achieving goals during the online learning period which can trigger academic stress. It is in line with (Hamzah \& Hamzah, 2020) which stated that the factor of college burden and self-adjustment can be a stressor received in the academic process. Students who are not able to adapt in environmental changes will affect the ability of adapting in stressors received from the academic process. So, it can bring up some stressor reactions, which can be seen in the table above, the emotion reaction has the highest score $64 \%$, and physical reaction was 54\%. Based on the finding, (Octasya \& Munawaroh, 2021) each individual physically has experienced all of the stress reactions generally such as headache and dizzy. Psychologically, they also experienced several emotion changes and behavior toward the pressure and the current conflict.

\section{Conclusion}

Based on the results of the research, It can be concluded that the profile of selfadjustment and the level of academic stress during the online learning period for the students of the engineering faculty of Universitas PGRI Adi Buana Surabaya was in the medium category with a percentage of $65 \%$. Furthermore, it is concluded in detail that self-adjustment was in the poor category with a percentage of $16.5 \%$, and the level of academic stress was in the high category with percentage of $18 \%$. Based on the percentage per aspects, the aspect of expressing feelings $(62 \%)$ was the lowest aspect felt by UNIPA Surabaya engineering students in the selfadjustment process during the online learning period. Academic stress on the aspect of change $(78 \%)$ was the highest aspect perceived by students, and the aspect of pressure $(77 \%)$. All in all, it can be concluded that the majority of engineering students at the Universitas PGRI Adi Buana Surabaya during the online learning period were still in a stable condition even facing the current environmental conditions and even there were some aspects that not too perfect in the selfadjustment process and the level of academic stress.

\section{References}

Argaheni, N. B. (2020). Sistematik Review: Dampak Perkuliahan Daring Saat Pandemi COVID19 Terhadap Mahasiswa Indonesia. PLACENTUM: Jurnal Ilmiah Kesehatan Dan Aplikasinya, 8(2), 99. https://doi.org/10.20961/placentum.v8i2.43008

Azwar, S. (2019). Penyusunan Skala Psikologi. Pustaka Pelajar.Yogyakarta

Chita Putri Harahap, A., Permatasari Harahap, D., \& Rivai Harahap, S. (2020). Analisis Tingkat Stres Akademik Pada Mahasiswa Selama Pembelajaran Jarak Jauh Dimasa Covid-19. Biblio 
Couns : Jurnal Kajian Konseling Dan Pendidikan, 3(1), 10-14.

Dixit, P. (2019). A study to assess and coping strategies coping strategies among adolecent studetns: A descriptive study. Indian Journal of Applied Research, 9(12), 9-10.

Gadzella, B., Baloglu, M., Masten, W., \& Wang, Q. (2012). Evaluation of the Student Life-Stress Inventory-Revised. Journal of Instructional Psychology, 39(2), 82.

Haber \& Runyon. (1984). Psychology of Adjustment. The Dorsey Press.

Handayani, P. G., \& Yuca, V. (2018). Fenomena Culture Shock Pada Mahasiswa Perantauan Tingkat 1 Universitas Negeri Padang. Jurnal Konseling Dan Pendidikan, 6(3), 198. https://doi.org/10.29210/129000

Hamzah, B., \& Hamzah, R. (2020). Faktor-faktor yang Berbubungan dengan Tingkat Stres Akademik. pada Mahasiswa Stikes Graba Medika. 4(2), 59-67.

Livana, Mubin Mohammad Fatkhul \& Basthomi, Y. (2020). Penyebab Stres Mahasiswa Selama Pandemi Covid-19. Jurnsl Ilmu Keperawatan Jiwa, 3(2), 203-208.

Moore, J. L., Dickson-deane, C., \& Galyen, K. (2011). Internet and Higher Education e-Learning , online learning, and distance learning environments : Are they the same? The Internet and Higher Education, 14(2), 129-135. https://doi.org/10.1016/j.iheduc.2010.10.001

Morissan. (2018). Metode Penelitian Survei (Pertama). Prenada Media Group

Nadlyfah, A. K., \& Kustanti, E. R. (2018). Hubungan antara Pengungkapan Diri dengan Penyesuaian Disi pada Mahasiswa Rantau di Semarang. 7(Nomor 1), 136-144.

Nurmalasari, Y., Yustiana, Y. R., \& Ilfiandra, I. (2016). Efektivitas restrukturisasi kognitif dalam menangani stres akademik siswa. Jurnal Penelitian Bimbingan Dan Konseling, 1(1).

Rosali, E. S. (2020). Aktifitas Pembelajaran Daring pada Masa Pandemi Covid-19 di Jurusan Pendidikan Geografi Universitas Siliwangi Tasikmalaya. 1, 21-30.

Safareka Yuliani. (2017). Hubungan Antara Konsep Diri Dan Dukungan Sosial Dengan Penyesuaian Diri Pada Siswa Kelas Vii Smp Negeri 11 Semarang Tabun Ajaran 2017/2018.

Sandra, R. (2015). Konsep Stres Kerja Guru Bimbingan dan Konseling. Jurnal EDUCATIO: Jurnal Pendidikan Indonesia, 1(2002), 80-85.

Sugiyono. (2018). No Title. In Metode Penelitian Pendidikan (Pendekatan Kuantitatif, Kualitatif dan R\&D). Alfabeta

Octasya, T., \& Munawaroh, E. (2021). Level of academic stress for students of guidance and counseling at Semarang State University during the pandemic. ProGCouns: Journal of Professionals in Guidance and Counseling, 2(1)..

Ward, C., Bochner, S., Furnham, A., Ward, C., Bochner, S., \& Furnham, A. (2001). Sojourners: International students. In T. \& F. E-Library (Ed.), The Psychology of Culture Shock (Second Edi). Routledge. https://doi.org/10.4324/9781003070696-10 